\title{
Medical Professionalism: the Effects of Sociodemographic Diversity and Curricular Organization on the Attitudinal Performance of Medical Students
}

\author{
Profissionalismo Médico: Efeito da Diversidade \\ Sociodemográfica e da Organização Curricular \\ no Desempenho Atitudinal dos Estudantes de \\ Medicina
}

\author{
Wilton Silva dos Santos \\ Jacob Arie Laros ${ }^{I I}$ \\ Eliana Mendonça Vilar Trindade \\ Manoel Dias Ribeiro Junior ${ }^{I}$ \\ Daniel Adriano Meneses da Silval \\ Leonardo Miranda Ribeiro
}

\section{KEYWORDS}

- Attitude of Health Personnel.

- Attitude Scale.

- Medicine Undergraduate.

- Academic Diversity.

- Medical professionalism.
REVISTA BRASILEIRA DE EDUCAÇÃO MÉDICA

\begin{abstract}
Introduction: Socioeconomic and demographic diversity in the educational environment and the development of professional attitudes enhance the quality of health care delivery. Despite the importance of diversity for equity and accessibility to health care, its repercussions for students' attitudinal learning have not been adequately evaluated. Purpose: Evaluate the influence of academic sociodemographic diversity and curricular organization in the development of professional attitudes in different phases of the undergraduate medical curriculum. Method: In 2012, the attitudinal performance of 310 socioeconomically diverse medical students was evaluated by the administration of a five-point professional attitudes scale. The participants were at different points in their education at a Brazilian public school of medicine in Brasilia, Federal District. The scale comprised 6 factors: communication, ethics, professional excellence, self-assessment, beliefs, social determinants; and a general factor called medical professionalism and was validated for the purpose of this research. The reliability coefficients (aCronbach) ranged from 0.65 to 0.87 , according to different scale dimensions. Student diversity was analyzed according to differences in gender, age, religious affiliation, system of student selection and socioeconomic background. Results: The authors observed a decline in the mean attitude scores during the clinical phase compared to the preclinical phase of the curriculum. Female students displayed more positive attitudes than male students, and the students who declared a religious affiliation recorded higher attitude scores compared to those who declared themselves atheist, agnostic or non-religious. There was no correlation between family income or the system of student selection and the students' attitude scores. The students who had attended public schools expressed a greater interest in working in the public health system compared to the other students. Age and marital status had no relevant effect on attitude scores. Conclusions: The attitude scores of medical students declined as the curriculum progressed. Female students had more positive attitudes than male students. Religious affiliation appeared to positively influence the observed attitude scores.
\end{abstract}

Superior School of Health Sciences - Brasilia, DF.

"University of Brasília, Brasília, DF, Brazil. 


\section{RESUMO}

\section{PALAVRAS-CHAVE}

- Atitude do Profissional de Saúde.

- Escala de Atitude.

- Graduação em Medicina.

- Diversidade acadêmica.

- Profissionalismo médico.
Introdução: A diversidade socioeconômica e demográfica no ambiente educacional e o desenvolvimento de attitudes profissionais estão associados ao aumento na qualidade da assistência em saúde. Apesar da importância dessa diversidade para a equidade e acessibilidade ao sistema de saúde, sua repercussão no aprendizado atitudinal dos estudantes em nosso meio ainda é muito pouco estudada e avaliada. Objetivo: Avaliar a influência das diferenças demográficas, sociais e econômicas e da organização curricular no desempenho atitudinal de estudantes de graduação em Medicina em diferentes fases do curso. Método: Em 2012, o desempenho atitudinal de 310 estudantes de Medicina foi avaliado mediante a aplicação de uma escala de atitudes profissionais de cinco pontos. Os participantes eram de diferentes séries do curso de graduação em Medicina de uma escola pública de Medicina de Brasília (DF). A escala de atitudes utilizada era composta por seis fatores - Comunicação; Ética; Excelência Profissional; Autoavaliação; Crenças; Determinantes Sociais; e um fator geral chamado Profissionalismo Médico - e foi validada para as finalidades desta pesquisa. O coeficiente de fidedignidade (a de Cronbach) para as diferentes dimensões da escala variou de 0,65 a 0,87. A diversidade dos estudantes foi avaliada de acordo com gênero, idade, religião, sistema de ingresso no curso (cotistas sociais/não cotistas) e condições socioeconômicas. Resultados: Os autores observaram um declínio nos escores médios de atitude em várias dimensões da escala durante a fase clínica, comparada à fase pré-clínica do currículo. Estudantes do gênero feminino obtiveram escores de atitudes mais positivos do que os do gênero masculino. Estudantes que declararam ter uma religião tiveram melhores escores do que os que se declararam ateus, agnósticos ou sem religião. Não houve correlação entre idade, estado civil e renda familiar e o desempenho atitudinal medido pela escala. Estudantes que ingressaram no curso pelo sistema de cotas expressaram maior interesse em trabalhar no sistema público de saúde. Conclusões: Houve um declínio do escore de atitude dos estudantes de Medicina com a progressão do curso. Estudantes do gênero feminino apresentaram escores de atitudes mais positivos que os do gênero masculino. Filiação religiosa parece influenciar positivamente o desempenho atitudinal dos estudantes.

Recebido em: 10/01/2017

Aprovado em: 14/07/2017

\section{INTRODUCTION}

Becoming a doctor requires professional socialization that involves both acquiring the knowledge and skills required for daily medical practice and the development and embodiment of the values, attitudes and behaviors essential to health care excellence. Although the vast majority of undergraduate medical curricula focus on knowledge acquisition and overemphasize the scientific aspects of professional training, the current demands of society point to a growing concern about the social and humanistic aspects of professional development ${ }^{1,2}$.

Medical professionalism refers to a set of attitudes and behaviors necessary to properly meet the demands of the profession. This term comprises several interrelated elements with imprecise limits, which, in general, express the ethical, moral and humanistic standards of good professional practices ${ }^{3}$.
In the last decade, the concept of professionalism has been linked to the concept of excellence in health care, including physicians' new responsibility to improve systems of care, act as stewards of health care resources and be sensitive and responsive to diversity in the patient population. Issues such as social justice, equity and quality of care have been incorporated into the principles and commitments of medical professionalism and endorsed by several medical organizations around the world ${ }^{4}$.

Social and demographic diversity in education is related to student differences in gender, age, and social, cultural, ethnic, religious and economic characteristics. Affirmative actions that enhance diversity in the educational environment have been recognized as tools to eliminate disparities in health care, provide culturally competent care and improve access to 
health care for the underserved. In this sense, similar to medical professionalism development, diversity is considered a tool to promote social justice, equity and the quality of care ${ }^{5,6}$.

The literature does not show a consensus about the benefits of diversity to developing professional attitudes. Some authors believe that a diverse student body enriches the educational environment and that students' exposure to different life experiences promotes a common understanding, empathic communication, social integration and collaborative learning ${ }^{6,7}$. Other authors fear that diversity could lead to difficulty with cohesion among the various groups, giving rise to communication difficulties at the organizational level and problems with transmitting and incorporating the essential values of the profession ${ }^{8,9}$. Despite the importance of diversity for social equity and accessibility to health care, the repercussions of diversity for students' attitudinal development still lack adequate evaluation.

Integrating medical professionalism learning activities into undergraduate curricula has been a difficult task. Such integrative actions involve issues related to innovation in education and the appropriate use of new teaching and assessment methods. In many situations, these changes imply the need to rethink the entire curriculum.

There is no consensus regarding the curriculum model that best integrates the teaching of medical professionalism. There is, however, a consensus that activities related to professional attitude development must be fully expressed in the curriculum at all phases of the student's education ${ }^{10,11}$. In terms of curricular organization, therefore, curricula that only occasionally address the development of professional attitudes must change to curricula that incorporate the development of professionalism into all phases of the student's education.

Teaching and evaluating students' professional development remains one of the most difficult core content areas in undergraduate medical education. The difficulty of identifying a valid and reliable instrument to measure attitudinal performance is reflected in the large number of measures aimed at assessing constructs related to medical professionalism that have been published to date ${ }^{12-14}$

Lynch et al. ${ }^{14}$, in a systematic review that included articles published in five databases from 1982 to 2002, identified 88 professionalism assessment instruments. The review authors classified these instruments into four categories according to content: ethics, personal characteristics, comprehensive professionalism and diversity. In the diversity category, the authors included variables related to student culture, socioeconomic status, gender and age.

Jha et al. ${ }^{13}$, in a systematic review that included 97 studies evaluating professionalism, identified three common types of measures: the direct administration of an attitude scale, responses to vignettes or scenarios exposing a conflict situation, and the direct administration of questionnaires. These measures were used both alone and in combination. The authors noted, however, that few studies provided details about how the items of the various instruments were developed and pointed out the difficulty of evaluating the psychometric quality of the measures employed.

This study was undertaken to determine the influence of academic diversity and curriculum organization on the attitudinal performance of medical students, as measured with a 50-item attitude scale previously validated for use with undergraduate medical students.

\section{METHODS}

\section{Context}

The graduate program in medicine at the Superior School of Health Sciences (SSHS) in Brasilia, Brazil, is a six-year curriculum serving 80 students per year. In 2004, the SSHS adopted a socioeconomically oriented admissions policy of affirmative action, reserving $40 \%$ of the admission slots for students coming from public secondary schools. Public schools in Brazil in general are designed for people with low family incomes. The representation of students from different backgrounds at the SSHS creates an environment of structural diversity. Because the school utilizes problem-based learning as its main educational strategy, students interact with one another frequently, learning in small discussion groups and creating functional diversity in the academic environment ${ }^{6}$.

\section{Participants}

The study sample comprised 310 students $(64.7 \%$ of all SSHS students), 158 in the preclinical phase of study (the first 3 years) and 152 in the clinical phase (the 4th year and internship). The numbers of students in the 1st, 2nd, 3rd, 4th, 5th and 6th school years were 57, 59, 42, 49, 67 and 36, respectively. For each 2-year educational cycle - initial, intermediate and internship - 116, 91 and 103 students were included, respectively. The participants' ages ranged from 18-47 years, with a mean of $23.2(\mathrm{SD}=3.6)$ and a median of 23 years. In the sample, 142 (45.8\%) students were male, and 168 (54.2\%) were female. Two hundred and twelve students (68.4\%) came from private schools, and 98 (31.6\%) came from public schools in Brasília.

\section{Instruments and research procedures}

The attitude scale used in the study was created by Miranda et $a .^{15}$. For the purposes of this research, the instrument was 
submitted to a process of construct validation utilizing factor analysis (FA). The FA procedures resulted in a 50-item Professional Attitudes Scale for Medical Students (PASMS-50) with 6 subscales (6 factors). The internal consistency measured with Cronbach's alpha ranged from $0.65-0.87$. We defined the conceptual structure of each subscale as follows ${ }^{16}$ :

Factor 1 (F1): Communication and human relations in health $(\alpha=0.87)$; Factor 2 (F2): Ethics in academic and medical practices $(\alpha=0.76)$; Factor 3 (F3): Professional excellence ( $\alpha=0.68)$; Factor 4 (F4): Importance of self-assessment for learning ( $\alpha=0.77)$; Factor 5 (F5): Beliefs in the context of medical education $(\alpha=0.65)$; Factor $6(\mathrm{~F} 6)$ : Importance of social determinants of health $(\alpha=0.67)$. Because the 6 factors were correlated, a general factor (GF) called Medical professionalism was developed based on the subscale scores $(\alpha=0.72)$.

The students indicated their level of agreement with the statements presented in each item using a five-point Likert scale (strongly agree, agree, undecided, disagree, strongly disagree). Approximately half of the items were formulated negatively, and the scores were corrected during the analysis procedures. We analyzed the scores based on the mean value obtained for each subscale assessed. Mean scores for attitudes $>3.0$ were considered to suggest a positive attitude toward the construct assessed.

We developed a questionnaire to obtain data regarding year of study, age, gender, marital status, religious affiliation, family income, admission according to secondary school (public or private) and future practice plans. These data were the basis for the diversity analysis proposed in the project.

After receiving research approval from the local Ethics Research Committee (Protocol 263/2012), we sent an email invitation to participate in this project to each student. The invitation contained the information the students would need to complete the questionnaire and the scale along with the schedule for participation. We administered the attitude scale and questionnaire to groups of students in the medical school auditorium during regular instruction activities between September and October 2012. The time required to complete both forms was approximately 30 minutes.

\section{Data analysis}

A descriptive analysis of the data was performed using mean standard deviation and amplitude of variation. Inferential analysis involving the comparison of the mean scores of the various subscales based on the diversity parameters that were analyzed was conducted using Student's $t$ test for independent samples. Comparisons involving three or more groups were performed using analysis of variance and additional procedures for comparing pairs (Bonferroni or Games-Howell, as appropriate). A correlation analysis involving continuous variables was performed using the Pearson coefficient $(r)$. The few comparisons of categorical variables were conducted utilizing the Chi-square method.

We evaluated the normality of data distribution according to the degree of skewness and kurtosis of the curves obtained from the scores of the 310 participants. Deviations from normality with an absolute value of skewness and kurtosis $<1.00$ were tolerated for the analytical procedures of the study $^{17}$.

We performed the analyses using the statistical programs included in version 20 of the Statistical Package for the Social Sciences (SPSS). Statistical significance was previously established at $\alpha=0.05$. The descriptive $p$ levels used to report the results were $p \leq 0.05, p \leq 0.01$, and $p \leq 0.001$. $p$ values between 0.05 and 0.10 were considered marginally significant.

The magnitude of the effects and correlations was estimated by calculating Cohen's $d$ effect size and was classified as follows: small: $\mathrm{d} \leq 0.20$; moderate: $0.20<\mathrm{d}<0.80$; and large: $\mathrm{d} \geq 0.80$. For data with readily available group variances, Eta $\left(\eta^{2}\right)$ values were used. The degree of the effect was considered small, medium or large when values were $0.10,0.30$ or 0.50 , respectively ${ }^{18,19}$.

\section{RESULTS}

This study examined the effect of diversity and curricular organization on medical students' attitudinal performance, as measured with a professional attitude scale (PASMS-50) validated for the purpose of this research. The 310 students' mean scores on each of the factors identified in the scale ranged from 3.05 (F5) to 4.79 (F6). The words "factor", "dimension" and "subscale" will be used interchangeably when reporting the results.

Students' performance according to the curriculum phases and cycles

The students' average performance on all subscales of the attitude scale during the preclinical phase $(n=158)$ ranged from 3.26 to 4.85 , whereas the scores of the students in the clinical phase $(n=152)$ ranged from 2.82 to 4.73 . With the exception of the self-assessment scale (F4), all differences were significant and showed a decline in the average student performance during the clinical phase ( $t$ test: independent samples). The magnitude of the correlation between the variables studied (measured using Cohen's $d$ effect size) was moderate for F1, F5 and GF (general factor), small for F3 and F6 and near moderate for F2 (Table 1). 


\begin{tabular}{|c|c|c|c|c|c|c|c|}
\hline & $\begin{array}{l}\text { Mean attitudinal scores }(\bar{x}) \text { on the } 50 \text {-it } \\
\text { preclinical and clinical phases of } \mathrm{m}\end{array}$ & $\begin{array}{l}\text { Pro } \\
\text { lical }\end{array}$ & $\begin{array}{r}\text { TABLE } 1 \\
\text { ssional Att } \\
\text { ining. Sup }\end{array}$ & $\begin{array}{l}\text { Scale (I } \\
\text { School }\end{array}$ & $\begin{array}{l}\text { S-50) of } \\
\text { alth Scic }\end{array}$ & $\begin{array}{l}\text { cal stude } \\
\text { - Brasilia }\end{array}$ & $\begin{array}{l}\text { the } \\
2\end{array}$ \\
\hline Fac & r/Subscale & & Phase & & Stu & $t$ test & \\
\hline & & & $\begin{array}{c}\text { Preclinical } \\
(\mathrm{n}=158)\end{array}$ & $\begin{array}{l}\text { Clinical } \\
(\mathrm{n}=152)\end{array}$ & $t$ value & $p$ value & $\begin{array}{l}\text { "d" effect } \\
\text { (Cohen) }\end{array}$ \\
\hline F1 & Communication and human relations in health & $\mathrm{x}$ & 4.36 & 4.05 & 548 & $n<0001 *$ & 063 \\
\hline & & SD & 0.45 & 0.53 & 5.48 & $p \leq 0.001^{\circ}$ & 0.03 \\
\hline $\mathrm{F} 2$ & Ethics in academic and medical practice & $\mathrm{x}$ & 4.75 & 4.60 & & & 0.39 \\
\hline & & SD & 0.35 & 0.43 & 3.40 & $p \leq 0.001^{*}$ & 0.39 \\
\hline F3 & Professional excellence & $\mathrm{x}$ & 4.43 & 4.29 & 277 & $0<005 *$ & 025 \\
\hline & & SD & 0.50 & 0.63 & 2.27 & $p<0.05$ & 0.23 \\
\hline $\mathrm{F} 4$ & Importance of self-assessment for learning & $\mathrm{x}$ & 4.29 & 4.35 & -066 & $n-051$ & 008 \\
\hline & & SD & 0.75 & 0.73 & -0.66 & $p=0.51$ & 0.08 \\
\hline F5 & Beliefs in the context of medical education & $\mathrm{x}$ & 3.26 & 2.82 & & & \\
\hline & & SD & 0.76 & 0.57 & 5.70 & $p \leq 0.001^{*}$ & 0.66 \\
\hline F6 & Importance of social determinants of health & $\mathrm{x}$ & 4.85 & 4.73 & 2.64 & $p<0.01^{*}$ & 0.30 \\
\hline & & SD & 0.37 & 0.43 & & & \\
\hline GF & Medical professionalism & $\mathrm{x}$ & 4.32 & 4.14 & 4.56 & $p \leq 0.001^{*}$ & 0.51 \\
\hline & & SD & 0.34 & 0.37 & 4.56 & $p \leq 0.001^{\circ}$ & 0.51 \\
\hline
\end{tabular}

* Statistical significance was set at $p \leq 0.05 . S D=$ standard deviation. GF $=$ General Factor.

We also conducted an analysis which involved dividing the course into 3 two-year cycles: initial, intermediate and internship. This analysis demonstrated that the average performance of the 3rd year students was higher than that of the 4 th year students for nearly all factors, and this difference was significant for F1 $(t=3.56, p \leq 0.001), \mathrm{F} 2(t=2.78, p<0.01)$ and GF $(t=2.44, p<0.05)$. The same results were not observed during the initial cycle (i.e., the 1st and 2nd year) or the internship cycle (i.e., the 5th and 6th year).

\section{Student performance according to gender}

Of the 310 students assessed, 168 (54.2\%) were female. The average performance of the female students on the examined factors ranged from 3.14 to 4.82 . The mean performance of the male students ranged from 2.93 to 4.75. Except for F4 and F6, the average performance of the women was higher than that of the men for all dimensions of the scale and for the GF ( $t$ test: independent samples). The estimated effect size (Cohen's d) showed a moderate degree of correlation between gender and the results for F1 and GF. The practical importance of the correlation that was analyzed for the remaining subscales was more discrete, with Cohen's $d$ at approximately 0.30 (Table 2).

When we performed an analysis of the participants' gender that considered the phases of the curriculum, we found that the women in the preclinical phase $(n=158,69 \hat{0}, 89$ ) achieved an average performance superior to that of the men in all dimensions of the scale (except F4); significance was observed for F1, F2, F3 and GF ( $t$ test, independent samples; $p \leq 0.05)$. Similarly, during the clinical phase $(n=152,73 \AA, 79+$ ), the averages of all the factors for the women were higher than those of the men; the differences were significant for F1, F5 and GF (ttest, $p<0.01)$.

\section{Students' performance according to religious affiliation} Two hundred and forty-two of the 310 (78.1\%) students included in the research answered the item related to religious affiliation. Of these, 119 (49.2\%) identified themselves as catholic, $49(20.2 \%)$ as protestant, $40(16.5 \%)$ as spiritualist and 33 (13.7\%) as "non-religious, atheist or agnostic". One (0.4\%) student identified with the category "other religions" and was excluded from the analysis.

In general, the means of the students who declared themselves "non-religious, agnostic or atheist" were lower than those of the students in the other religious affiliation groups for nearly all factors. Significant differences were observed for F1 and GF among those who declared themselves catholic and spiritualist compared with those who declared themselves "non-religious, atheist or agnostic". More positive attitudes were also observed for F3 (professional excellence) among the students who identified themselves as spiritualist compared with those who identified as "non-religious, atheist or agnostic". The students who did not answer the item were included in the analysis and showed a higher attitudinal performance compared to the students who declared themselves "non- 


\begin{tabular}{|c|c|c|c|c|c|c|c|}
\hline & $\begin{array}{r}\text { Mean attitudinal performance score } \\
\text { Attitude Scale for Medical S }\end{array}$ & $\begin{array}{l}(\bar{x}) \text { a } \\
\text { Iden }\end{array}$ & $\begin{array}{l}\text { TABLE } \\
\text { ding to } \\
\text { aperior }\end{array}$ & $\begin{array}{l}\text { measur } \\
\text { of Healt }\end{array}$ & $\begin{array}{l}\text { ig the } 50 \\
\text { nces - B }\end{array}$ & $\begin{array}{l}\text { Profess } \\
\text { a, } 2012\end{array}$ & \\
\hline Fact & r/Subscale & & Ger & & Stuc & $t$ test & \\
\hline & & & $\begin{array}{l}\text { Female } \\
(n=168)\end{array}$ & $\begin{array}{c}\text { Male } \\
(\mathrm{n}=142)\end{array}$ & $t$ value & $p$ value & (Cohen) \\
\hline F1 & Communication and human relations in health & $\mathrm{x}$ & 4.32 & 4.08 & -408 & $n<0001$ * & 047 \\
\hline & & SD & 0.46 & 0.56 & -4.08 & $p<0.001^{n}$ & 0.47 \\
\hline F2 & Ethics in medical practice and academic & $\mathrm{x}$ & 4.73 & 4.61 & & & \\
\hline & & SD & 0.37 & 0.43 & -2.68 & $p<0.01^{*}$ & 0.30 \\
\hline F3 & Professional excellence & $\mathrm{x}$ & 4.44 & 4.26 & -266 & $n \leq 0 \cap 01 *$ & 031 \\
\hline & & $\mathrm{SD}$ & 0.47 & 0.66 & -2.66 & $p<0.01^{*}$ & 0.31 \\
\hline F4 & Importance of self-assessment for learning & $\mathrm{x}$ & 4.34 & 4.29 & -0.66 & $n=0.51$ & 0.07 \\
\hline & & SD & 0.70 & 0.79 & -0.60 & $p=0.31$ & \\
\hline F5 & Beliefs in the context of medical education & $\mathrm{x}$ & 3.14 & 2.93 & 266 & $n \leq 001 *$ & 030 \\
\hline & & SD & 0.65 & 0.76 & -2.60 & $p<0.01^{\circ}$ & 0.30 \\
\hline F6 & Importance of social determinants of health & $\mathrm{x}$ & 4.82 & 4.75 & -146 & $n=014$ & 017 \\
\hline & & SD & 0.42 & 0.38 & -1.40 & $p=0.14$ & 0.17 \\
\hline & Medical professionalism & $\mathrm{x}$ & 4.30 & 4.15 & $-3,47$ & $n<0,001 *$ & 0.40 \\
\hline & & SD & 0.32 & 0.41 & -0.47 & $p \leq 0.001$ & 0.40 \\
\hline
\end{tabular}

* Statistical significance at $p \leq 0.05 . S D=$ standard deviation. GF $=$ General Factor.

religious, atheistic, or agnostic"; however, this difference was only observed for the F1 subscale (analysis of variance with Bonferroni correction).

We conducted an analysis by dividing the sample into two groups: those who reported observing any religion $(\mathrm{n}=209 ; 86.4 \%)$ and those who declared themselves "non-religious, atheist or agnostic" ( $n=33 ; 13.6 \%)$. The means of the first group (ranging from 3.04 to 4.80 ) were higher than those of the second group (ranging from 2.95 to 4.73 ) for all subscales and were significant for F1, F3, and F4 and GF ( $t$ test, independent samples: all $p$ values $<0.05)$. The magnitude of the relationship among these variables (estimated using Cohen's $d$ ) ranged from $0.35(\mathrm{~F} 4)$ to $0.60(\mathrm{~F} 3)$, revealing a small-to-moderate practical significance. The same analysis was used to compare the group that declared having a religion with the group that left the item blank, and no significant difference in any of the factors was found. Regarding the phases of medical training, the analysis also showed significance for F1 during the preclinical phase and for F1 and GF during the clinical phase.

\section{Students' performance according to admission policy and future practice plans}

The study sample $(n=310)$ comprised 98 (31.6\%) students from secondary public schools and 212 medical students (68.4\%) from private secondary institutions. The average scores of the public school medical students ranged from 3.06 to 4.78 . These scores are strikingly similar to those of the students who came from the private educational system, which ranged from 3.04 to 4.79 . Therefore, there were no differences in student attitudinal performance related to the SSHS admissions policy ( $t$ test, independent samples, with $p>0.05$ for all factors). The analysis for this variable that considered the different phases of study showed similar results.

The item regarding the students' future career addresses their future professional plans in the work market and examines the interest in public service (National Public Health System) versus the private market. The percentage of medical students from public schools who had a primary interest in working in the public health system or in family programs was $19.8 \%(16 / 80)$, whereas only $8.4 \%(16 / 186)$ of the medical students from private schools expressed this interest. This difference was significant (chi-square, $\chi 2$ calculated $=6.87$, $p<0.01)$.

\section{Students' performance according to family income}

We obtained information about family income from 236 students (76.1\%). Sixty-two of the 236 (26.3\%) came from public schools, and 174 (73.7\%) came from private education systems. For the purposes of this research, family income (in terms of monthly minimum income) was grouped into five categories: $1-2,2-5,5-10,10-15$ and $\geq 15$ times the minimum wage (the Brazilian monthly minimum wage=US\$311.00). Of the medical students who came from public schools, $75.8 \%$ reported a family income of less than 10 times the minimum wage; among 
the medical students who came from private schools, $79.3 \%$ reported a family income greater than 10 times the minimum wage. Thus, as expected, there was a positive correlation between lower income and public school origin (Pearson correlation coefficient, $r=0.57$ ). There was no correlation between attitude scores and family income (Pearson coefficient ranging from 0.07 to 0.11 ) for any of the subscales of the PASMS-50.

\section{Students' performance according to age and marital status}

The participants' ages ranged from 18-47 years old with a mean of $23.21(\mathrm{SD}=3.59)$ and a median of 23 years old. In general, significant differences were observed only at the extremes of the age range ( $<20$ and $\geq 26$ years old), and these differences were attributed to differences in the phases of the medical curriculum, as previously mentioned. The vast majority of the participants were single $(93.5 \%, \mathrm{n}=290)$, which limited this type of analysis. Considering this limitation, no differences in attitudinal scores related to marital status were observed for almost the entire factor analysis.

\section{DISCUSSION}

The assessment of the students' professional development throughout the curriculum and the adoption of affirmative action that favors diversity have received increasing attention in the literature because of the recognized association between these policies and excellent care delivery.

The teaching and learning of attitudes associated with good professional medical practice have been acknowledged as essential aspects of medical education; thus, there is a growing consensus that educational experiences that develop the students' professional attitudes must be explicitly included in the curriculum ${ }^{13,20}$. Planning for the development of this learning throughout the course of study and assessing student progress in accordance with the cycles of learning are challenging tasks that involve observing and examining the subjectivity inherent in moral, ethical and humanistic approaches to medical practice.

The scores of the students in the preclinical phase of the curriculum indicated that they had more positive attitudes compared with the students in the clinical phase for nearly all the dimensions of the scale used. The estimated magnitude of the effect was relevant for F1, F2 and GF, indicating that in addition to their statistical significance, these results bear practical significance.

The decline of students' attitudinal performance over the course of their undergraduate studies has been observed for decades and has been widely described in both cross-sectional and longitudinal studies ${ }^{21-25}$. Increased cynicism and econom- ic interests and decreased humanistic and social values and ethical judgment abilities have been acknowledged during the medical training process $\mathrm{s}^{21,24,25}$.

Similarly, some studies have reported superior student performance in the final coursework stages in many of the fields covered in this study and also the stability of these constructs, providing a counterpoint for the observations cited above $^{15,23,24,26}$

The negative effect of the course of study on students' attitudinal training can be analyzed from the perspective of student and curriculum characteristics. Regarding the students' personal characteristics, some authors associate the decline in students' attitudes with a loss of idealism. As the medical curriculum progresses, students adopt a more realistic view of the profession and a more critical opinion of the curriculum and of medical education. Furthermore, over time, students can lose interest in issues related to professional training, and this lack of interest can be reflected in the students' performance on questionnaires and scales, such as the ones used in this study. This attitude can compromise the interpretation of results of the instrument as a whole or its domains ${ }^{21,25}$. Regarding the curriculum, many authors suggest that the loss of interest in the psychosocial aspects of doctor-patient interaction and the low scores on scales that address the social aspects of medicine are essentially linked to the biomedical model that most medical schools adopt. Content related to professional attitudes is scarce and is restricted to the early stages of the curriculum. Learning activities focus more on the hospital and less on the community, and the emphasis is on disease and not on the sick person. Consequently, the curriculum ultimately negatively affects students' retention or acquisition of positive attitudes in the fields that the studied instrument addresses ${ }^{11,21,27}$.

Remarkably, in the SSHS medical curriculum, the content related to formal "communication and professional attitudes" education is taught only until the 3rd year of the program (i.e., the preclinical phase). During the last three years of medical school, there are no formally structured activities that focus on developing medical professionalism. The results of this study indicate a decline in scores during that phase. When the data were evaluated to better determine the dynamics of this decline, we observed the greatest reduction in the students' performance during the intermediate cycle (i.e., between the $3 \mathrm{rd}$ and 4 th school years). These data indicate the need to revise the curriculum and extend the teaching of professional attitudes to the clinical phase of the curriculum, as several authors have suggested ${ }^{8,10-12}$.

The lowest scores throughout the course of study were related to the social determinants of health, a finding that may 
be explained by aspects of the curriculum. As an example, the SSHS medical curriculum, despite the innovative methodologies adopted, favors the biomedical model of illness, which overemphasizes the biological factors of the health-disease process to the detriment of psychosocial factors. This imbalanced focus can have a negative effect on the learner's valuation and incorporation of the social aspects of the disease process as he/she progresses through the curriculum.

Another notable consideration is that students in the clinical phase of the program are more exposed to the influences of the practice environment and are more vulnerable to the effects of the hidden curriculum. We must consider that the limitations, pressures and values espoused by the institution may have deleterious effects on students' education and can compromise their professional development $t^{11,21,28}$.

In the analysis of gender, the attitudinal performance of the female students was consistently higher than that of male students, regardless of the stage of study. The reasons for these differences are not completely clear because both genders had similar educational experiences throughout the curriculum. According to some authors, women assign more importance than men do to the relational and psychosocial aspects of patient care ${ }^{29}$. In addition, based on patients' opinions, women are more thoughtful and more "human" than their male coworkers ${ }^{23,29}$. Gender roles encompass the previously established expectations and behavioral models that are built into social structures. In this sense, caring, nurturing and sensitivity to affective issues are roles and dimensions of social behavior that are generally associated with the female gender. All of these aspects of feminine roles in society are aligned with the social and affective domains of medical formation. In fact, several reports in the literature show that women have more positive attitudes than men regarding several elements of medical professionalism. Communication, doctor-patient relationships, ethics and social factors are dimensions of professional attitudes in which the superior performance of women is well documented ${ }^{21,23,26,27}$. This study provides further evidence of gender differences that favor women, who showed more positive attitudes than men did on 4 subscales and on the GF.

Students under the age of 20 years had higher scores than students over the age of 26 years did on F2, F5, F6 and GF. Because all of the students under 20 years old were in the preclinical phase and the majority of the students older than 26 years were in the clinical phase of study, many of the observed results were interpreted as differences that developed during different stages of the curriculum, as discussed above.

We observed that students with a religious affiliation had more positive attitudes than the non-religious students did for the majority of the analyzed subscales. The relationship between religion and some aspects of professionalism derives from the fact that religious practices promote helping and caring for others and encouraging altruism, kindness, generosity and other attitudes and behaviors that promote good human relationships and efficient social support. These prescriptions are aligned with some dimensions of the professional attitudes examined in this study and may explain some of the results observed for the students who declared a religious affiliation ${ }^{30}$. However, we did not find similar results regarding religious affiliation in the literature.

The socioeconomic diversity of our sample is related to the SSHS admission policy. The students from public schools were much more likely to have lower family incomes compared with the students from private schools. The SSHS admissions system creates an academic environment characterized by social and economic diversity. Although some authors believe that this type of diversity can lead to difficulties with cohesion among groups and hamper the transmission and apprehension of the core values of the profession ${ }^{8,9}$, our research has not corroborated this view. In fact, in our study, the mean attitude scores of the students from the public school system (i.e., those with the lowest family incomes) were remarkably similar to the scores of the students from private schools.

There is ample evidence that the representation of minority segments of society in health-related academic courses is associated with an improved quality of the health services delivered to socioeconomically vulnerable populations because students from these minority groups are more likely to choose careers or areas of expertise that will benefit these underserved populations. This study corroborates this observation because when we compared the two studied groups' responses to the item "future practice plans", we observed that the students from public schools reported an increased interest in working in the public health system and in government-supported family health services. This result is consistent with the view that socioeconomic diversity in the academic environment of health professions works to promote social justice, democratize care and reduce health care inequalities ${ }^{31}$.

\section{CONCLUSION AND FINAL CONSIDERATIONS}

The students' attitude scores declined during the last three years of medical school for the majority of the factors that were studied using the 50-item Professional Attitudes Scale for Medical Students (PASMS-50), which was previously validated for the purpose of this research. Different types of diversity in the educational environment influenced the students' attitudinal performance, regardless of curricular organization. 
The female students had more positive attitudes than the male students did for 4 dimensions of the scale and the GF. The students who declared a religious affiliation showed more positive attitudes compared with the non-religious students, atheists or agnostics. Socioeconomic diversity did not influence the students' attitudinal performance. The medical students from public schools expressed greater interest in working in the public health system or in government-supported family health programs.

The study had a cross-sectional design and compared different groups of medical students at different stages of their training. A longitudinal design comparing the same group of students would provide more sound and reliable results. The lack of a longitudinal design in this study weakens the results related to the phases of the curriculum.

\section{REFERENCES}

1. Arnold L. Assessing professional behavior: yesterday, today, andtomorrow. Acad Med. 2002;77(6):502-15.

2. Frenk J, Chen L, Bhutta ZA, Cohen J, Crisp N, Evans T, Fineberg H, Garcia P, Ke Y, Kelley P, Kistnasamy B, Meleishttp:/ / www.ncbi.nlm.nih.gov/pubmed/?term=Meleis $\% 20$ A \% 5 B A u thor \% 5 D \& c a u thor =true \& c a u thor uid=21112623A, Naylor D, Pablos-Mendez A, Reddy S, Scrimshaw S, Sepulveda J, Serwadda D, Zurayk H. Health professionals for a new century: transforming education to strengthen health systems in a interdependent world. Lancet. 2010; 376(9756):1923-58.

3. Martimianakis MA, Maniate JM, Hodges BD. Sociological interpretations of professionalism. Med Educ. 2009; 43(9):829-37.

4. Lesser CS, Lucey CR, Egener B, Braddock CH, Linas SL, Levinson W. A behavioral and systems view of professionalism. JAMA. 2010; 304(24):2732-7.

5. Cohen JJ, Gabriel BA, Terrell C. 21(5):90-102. Available at: http:/ / content.healthaffairs.org/cgi/doi/10.1377/hlthaff.21.5.90. Accessed in 12/01/2013.

6. Milem JF. The educational benefits of diversity: Evidence from multiple sectors. In: Compelling interest: Examining the evidence on racial dynamics in higher education. Chang M, Witt D, Jones K, Hakuta K, eds. Palo Alto (CA): Stanford University Press; 2003. p 126-69. Retrieved from: http: / / www.stanford.edu/ hakuta / www / policy / racial_dynamics/Chapter5.pdf. Acessed in 25/01/2013.

7. Bollinger LC. The need for diversity in higher education. Acad Med. 2003;78(5):431-36.

8. Cruess SR, Cruess RL. Professionalism must be taught. BMJ. 1997; 315(7123):1674-7.
9. Cox TH Jr. Group identities in the self-concept. In: Cultural diversity in organizations: Theory, research and practice. 1st ed. Cox T, ed. San Francisco (CA): Berrett-Koehler; 1993. p 43-63.

10. Arnold L, Stern DT. What is medical professionalism? In: Measuring medical professionalism. 1st ed. Stern DT, ed. New York (NY): Oxford University Press; 2006. p. 15-37.

11. Stephenson A, Higgs R, Sugarman J. Teaching professional development in medical schools. Lancet. 2001;357(9259):86770.

12. Passi V, Doug M, Peile E, Thistlethwaite J, Johnson N. Developing medical professionalism in future doctors: A systematic review. Int J Med Educ. 2010;1:19-29.

13. Jha V, Bekker HL, Duffy SRG, Roberts TE. Perceptions of professionalism in medicine: A qualitative study. Med Educ. 2006; 40(10):1027-36.

14. Lynch DC, Surdyk PM, Eiser AR. Assessing professionalism: A review of the literature. Med Teach. 2004;26(4):366-73.

15. Miranda SM, Pires MM, Nassar SM, Silva CAJ. Construção de uma escala para avaliar atitudes de estudantes de medicina. Rev Bras Educ Med. 2009; Suppl 33:104-10.

16. Santos WS, Laros JA. Professional Attitudes Scale for Medical Students - validation and assessment of students' performance according to their social and demographic characteristics. [master's thesis]. [Brasília (Brazil)]: Superior School of Health Sciences; 2013. p1-47.

17. Miles J, Shevlin M. Assumptions in regression analysis. In: Applying regression and correlation: A guide for students and researchers. 1st ed. Miles J, Shevlin M, eds. London (UK): Sage; 2001.p 58-112.

18. Field A. Correlação. In: Descobrindo a estatística usando o SPSS [Discovering Statistics Using SPSS]. 2nd ed. Field A, ed. Porto Alegre (Brazil): Artmed; 2009. p 125-55.

19. Vacha-Haase T, Thompson B. How to estimate and interpret various effect sizes. J Couns Psychol. 2004; 51(4):473-81.

20. Cruess SR, Cruess RL. The cognitive base of professionalism. In: Teaching medical professionalism. 1st ed. Cruess RL, Cruess SR, Steinert Y, eds. New York (NY): Cambridge University Press; 2009. p 7-27.

21. Woloschuk W, Harasym PH, Temple W. Attitude change during medical school: A cohort study. Med Educ. 2004; 38(5):522-34.

22. Masson N, Lester $\mathrm{H}$. The attitudes of medical students towards homeless people: Does medical school make a difference? Med Educ. 2003; 37(10):869-72.

23. Price J, Price D, Williams G, Hoffenberg R. Changes in medical student attitudes as they progress through a medical course. J Med Ethics. 1998; 24(2):110-7. 
24. Wolf TM, Balson PM, Faucett JM, Randall HM. A retrospective study of attitude change during medical education. Med Educ. 1989; 23(1):19-23.

25. Rezler AG. Attitude changes during medical school: a review of the literature. J Med Educ. 1974; 49(11):1023-30.

26. De Monchy C, Richardson R, Brown RA, Harden RM. Measuring attitudes of doctors: The doctor-patient (DP) rating. Med Educ. 1988; 22(3):231-39.

27. Haidet P, Dains JE, PaternitiDA, Hechtel L, Chang T, Tseng E, Rogers JC. Medical student attitudes toward the doctor-patient relationship. Med Educ. 2002; 36(6):568-74.

28. Lempp H, Seale C. The hidden curriculum in undergraduate medical education: Qualitative study of medical students' perceptions of teaching. BMJ. 2004; 329:770-73.

29. Maheux B, Dufort F, Lambert J, Berthiaume M. Do female general practitioners have a distinctive type of medical practice? CMAJ. 1988;139(8):737-40.

30. Koenig HG. Religion and medicine II: Religion, mental health, and related behaviors. Int J Psychiatry. 2001; 31(1):97109.

31. Association of American Medical Colleges - AAMC. Striving toward excellence: Faculty Diversity in Medical Education. (2009): pp.1-52. Retrieved from https://members. aamc.org/eweb/upload/Striving\%20Towards\%20Excellect $\% 20$ Faculty $\% 20$ Diversity\%20in\%20Med \%20Ed.pdf. Acessed in 17/01/2013.

\section{ACKNOWLEDGMENTS}

The authors would like to thank Stewart Mennin for his guidance during the Masters in Health Professions Education programme in Brazil and his critical thinking and support.

\section{ETHICAL APPROVAL}

Ethical approval for this study was granted by the Ethics Research Committee of the Teaching and Research in Health Sciences Foundation of Brasília, DF, Brazil (Protocol 263/2012).

\section{CONTRIBUTIONS}

All the authors participated in planning, execution and final preparation of this research manuscript.

\section{CONFLICT OF INTERESTS}

None.

\section{FUNDING}

None.

\section{POSTAL ADDRESS}

Wilton Silva dos Santos

SQN 304 - bloco A - apto 509

Asa Norte - Brasília

CEP 70736-010 - DF - Brazil

E-mail: wiltonss@uol.com.br 